\title{
ANALISIS LINGKUNGAN STRATEGIS UNTUK MENINGKATKAN KOMPETITIFITAS PRODUK PERBANKAN
}

\author{
Kunto Ajibroto \\ Politeknik Pajajaran ICB Bandung \\ Hendriady de Keizer \\ Politeknik Pajajaran ICB Bandung \\ Dematria Pringgabayu \\ Politeknik Pajajaran ICB Bandung \\ Email: dematria.pringgabayu@ poljan.ac.id
}

\begin{abstract}
ASBTRAK
Analisis lingkungan strategis merupakan bagian dari komponen perencanaan strategis dan merupakan proses untuk selalu menempatkan perusahaan dalam posisi strategis, sehingga dalam perkembangannya akan selalu berada pada posisi yang menguntungkan. Tujuan penelitian ini adalah untuk menganalisis faktor eksternal dan faktor internal, sehingga dapat diketahui formulasi strategi yang paling tepat untuk BPR Bhakti Daya Ekonomi dalam menghadapi persaingan yang semakin ketat. Metode penelitian yang digunakan adalah kualitatif dengan pengumpulan data menggunakan wawancara dan observasi, sedangkan untuk analisis data menggunakan metode SWOT yang juga menggunakan analisis EFAS dan IFAS. Hasil penelitian ini menunjukkan bahwa posisi BPR Bhakti Daya Ekonomi untuk produk Kredit Karyawan berada di kuadran IV. Dalam kuadran ini bank berada dalam posisi di mana keunggulan internalnya relatif lebih dominan daripada kelemahannya. Namun, dalam menghadapi lingkungan ancaman relatif lebih besar daripada peluang. Para penulis merekomendasikan bahwa BPR Bhakti Daya Ekonomi harus menerapkan strategi diversifikasi yang terkonsentrasi sementara berfokus pada kredit karyawan tidak hanya melayani pegawai negeri sipil dan TNI / POLRI, tetapi menambahkan produk baru yang merupakan pinjaman karyawan swasta yang secara khusus menargetkan pasar karyawan swasta dengan pendapatan tetap.
\end{abstract}

Kata Kunci: Analisis SWOT, Strategi Kompetitif, Industri Perbankan 


\section{PENDAHULUAN}

Peraturan yang ditetapkan oleh pemerintah tentang perbankan membatasi ruang Bank Perkreditan Rakyat (BPR) dengan larangan dalam kegiatan usahanya sebagaimana tercantum dalam pasal 13 Prinsip Perbankan yang menyatakan bahwa BPR dilarang: (a) Menerima setoran dalam bentuk giro dan berpartisipasi dalam lalu lintas pembayaran; (B) Melakukan kegiatan bisnis dalam mata uang asing; (c) Untuk terlibat dalam partisipasi ekuitas; (d) Melakukan bisnis asuransi; (e) Melakukan usaha selain kegiatan usaha sebagaimana dimaksud dalam pasal 13. Bahwa kegiatan yang diperbolehkan adalah: (a) Mengumpulkan dana dari masyarakat dalam bentuk deposito berjangka, tabungan dan / atau bentuk lain yang setara; (b) Berikan kredit; (c) Untuk menyediakan pembiayaan bagi pelanggan atas dasar bagi hasil sesuai dengan ketentuan yang diatur dalam peraturan pemerintah; (d) Menempatkan dana dalam bentuk deposito berjangka Sertifikat Bank Indonesia (SBI), sertifikat deposito, dan / atau tabungan di bank lain.

Ruang terbatas ini membuat BPR sulit menembus segmen pasar bank komersial, tetapi sebaliknya untuk melihat risiko kecil yang ada di BPR dalam pencairan kredit (jumlah pinjaman yang terkait dengan agunan) dan dalam pengumpulan dana juga relatif kecil yang telah menjadi pangsa pasar BPR yang mulai dilirik oleh bank umum, ini merupakan ancaman serius bagi BPR. Memang, sampai saat ini peraturan dari pemerintah yang mengatur ruang untuk akses bank komersial untuk memasuki daerah pedesaan belum ada, di sinilah celah dimanfaatkan oleh bank komersial untuk memperluas jaringannya dengan membuka kantor kasnya. Sementara BPR terus bertahan dengan segala keterbatasannya. Berdasarkan sumber data yang tersedia di Bank Indonesia hingga tahun 2014, di Daerah Istimewa Yogyakarta (DIY) saja terdapat 9 cabang bank pemerintah (BUMN), 19 cabang Bank Umum Nasional Swasta, 65 BPR, 101 Unit Bank Rakyat Indonesia (BRI), 147 Bank Kredit Cabang (BKD) dan 9 Badan Kredit Perkreditan Rakyat (BUKP) dan ini merupakan tantangan yang cukup berat untuk dapat melawan sisa "kue" yang tersisa.

Persaingan yang sangat ketat ini membuat BPR khususnya di Yogyakarta harus membuat dan merumuskan strategi yang tepat, tingkat bunga peperangan bukan hal yang tabu dan aneh bagi bank, strategi pembagian hadiah juga semakin meluas dan menjamur atau strategi mengambil bola juga "trik" yang sering dilakukan untuk menarik pelanggan. Perang "kemampuan" yang tidak seimbang dalam bisnis perbankan ritel inilah yang menyebabkan pangsa pasar BPR menjadi lebih kecil. Melihat kondisi ini BPR mau tidak mau harus segera 
membangun dan mengembangkan strategi pemasaran yang tepat untuk dapat mempertahankan dan mengembangkan segmen pasarnya.

Perjuangan pasar dengan bank komersial yang baru-baru ini merajalela antara lain adalah pada produk kredit, terutama pinjaman yang diberikan kepada Pegawai Negeri Sipil, Angkatan Darat dan Polisi atau sering disebut Kredit Karyawan.

\section{TELAAH PUSTAKA}

\section{Konsep Strategi}

Porter (2008) menjelaskan bahwa strategi itu unik dan berharga, melibatkan serangkaian kegiatan yang berbeda. Ketika kita telah memberikan atau menawarkan sesuatu secara berbeda dari apa yang telah kita lakukan sebelumnya, mereka disebut strategi. Strategi juga dapat dikatakan sebagai inti manajemen secara umum yang mencakup menggambarkan posisi perusahaan, membuat beberapa tarikan dan menempa setiap kegiatan dengan tepat. Strategi juga didefinisikan sebagai penciptaan timbal balik dalam kompetisi, menggabungkan kegiatan, serta menciptakan konformitas antaraktivitas yang dilakukan oleh perusahaan Keberhasilan perusahaan dalam mencapai tujuannya tergantung pada keberhasilan orangorang di perusahaan menerapkan strategi baik di tingkat perusahaan dan fungsional dan pada tingkat operasional. Noe et al (2009) mengatakan bahwa pembentukan strategi sangat penting bagi perusahaan untuk mencapai tujuan yang dinyatakan, terlepas dari apakah perusahaan adalah layanan publik atau perusahaan yang berorientasi laba. Dalam menentukan strategi beberapa faktor kunci keberhasilan untuk menetapkan strategi yang efektif harus diidentifikasi. Keterlambatan dalam mengenali faktor-faktor kunci keberhasilan akan berdampak pada kesuksesan perusahaan.

Menurut Rangkuti (2006), ada dua konsep strategis untuk mencapai tujuan yaitu: 1. Distinctive Competitive

Itu adalah perusahaan yang memiliki kekuatan yang tidak mudah ditiru dan lebih baik daripada perusahaan pesaing, dan kemampuan spesifik perusahaan sangat bergantung pada: Sebuah. Keterampilan tenaga kerja. Kemampuan sumber daya yang ada.

Kedua faktor ini menyebabkan perusahaan lebih unggul dari pesaingnya. Keterampilan sumber daya manusia yang lebih tinggi timbul dari kemampuan untuk membentuk fungsi khusus yang lebih efektif dibandingkan dengan pesaing. 


\section{Keunggulan Kompetitif}

Itu adalah kegiatan khusus yang dikembangkan oleh perusahaan untuk menjadi lebih unggul dibandingkan dengan pesaingnya, untuk itu diperlukan perencanaan strategis yang benarbenar matang dan teliti.

Lingkungan perusahaan tidak hanya semakin mudah berubah dalam beberapa tahun terakhir tetapi juga terkait erat. Dengan semakin ketatnya persaingan dalam bisnis perbankan akhirakhir ini menyebabkan banyak perubahan pada sistem tidak terkecuali di BPR Bhakti Daya Ekonomi. Dinamika seperti itu membutuhkan tanggapan serius dari perusahaan. Pertama, perusahaan harus berpikir secara strategis, yang jarang dilakukan sebelumnya. Kedua, perusahaan harus menerjemahkan masukan mereka untuk strategi yang lebih efektif untuk mengatasi perubahan lingkungan mereka. Ketiga, perusahaan harus mengembangkan alasan yang diperlukan untuk meletakkan dasar untuk penggunaan dan penerapan strategi.

\section{Strategi Kompetitif}

Setiap perusahaan yang bersaing dalam suatu industri memiliki strategi bersaing yang dikembangkan melalui proses perencanaan atau mungkin telah dikembangkan melalui kegiatan berbagai departemen fungsionalnya. Menurut Porter (2008) strategi bersaing adalah kombinasi dari tujuan yang diperjuangkan oleh perusahaan dengan alat di mana perusahaan berusaha untuk sampai ke sana. Untuk merumuskan strategi bersaing tetap menurut Porter harus mempertimbangkan 4 (empat) faktor utama yang menentukan batasan yang dapat dicapai oleh perusahaan seperti pada gambar 1 .

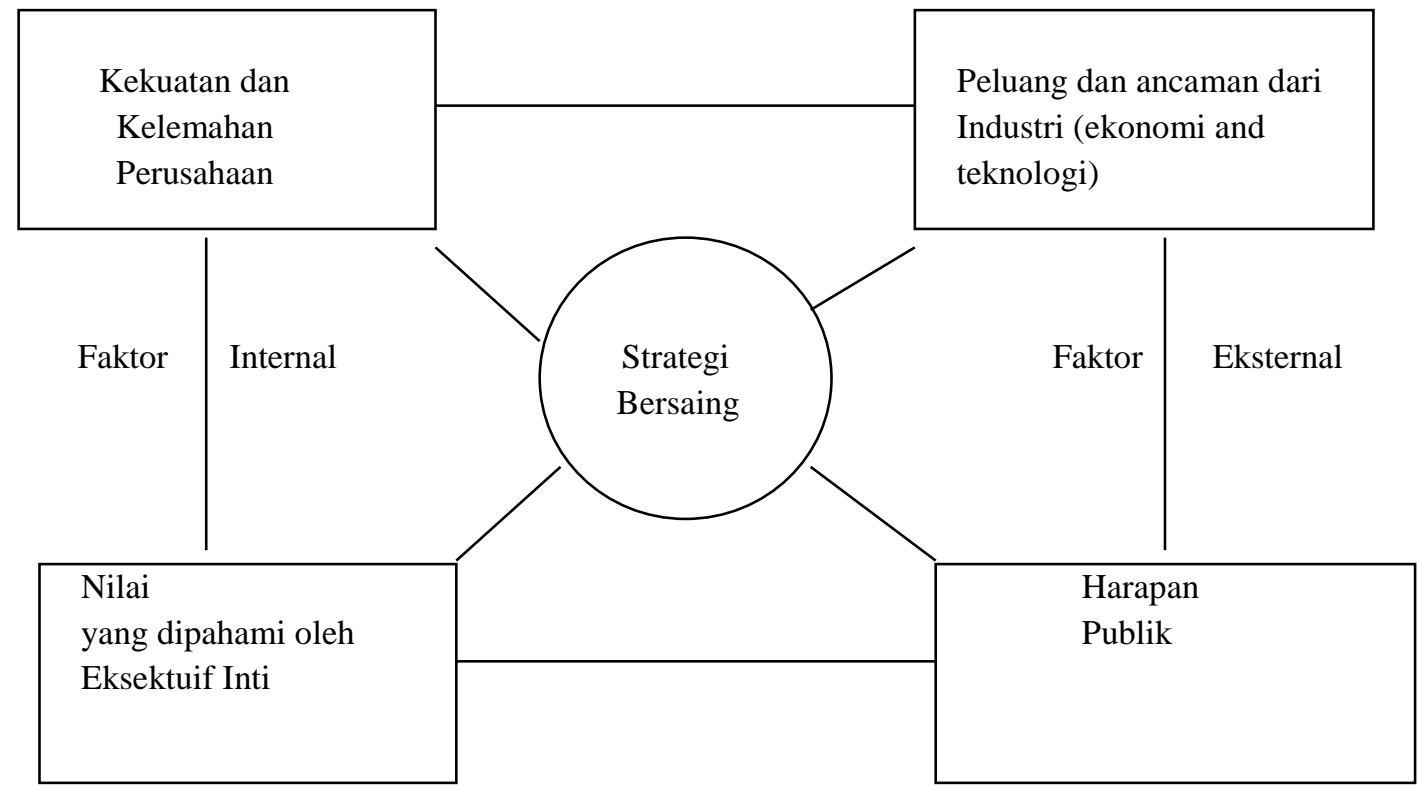

Gambar 1. Konteks Perumusan Strategi Persaingan

(Porter, 2008) 
Dengan demikian rumusan utamanya adalah menghubungkan perusahaan dengan lingkungan sosialnya, kekuatan ekonomi dan pesaing itu sendiri, di mana kuncinya terletak pada kemampuan perusahaan untuk mengatasinya. Tujuan dari strategi bersaing adalah untuk menemukan posisi perusahaan di mana perusahaan dapat melindungi dirinya dari tekanan persaingan atau secara positif mempengaruhi tekanan. Kekuatan gaya kompetisi dalam suatu industri menentukan tingkat pengembalian ke tingkat pasar bebas sehingga juga mengendalikan kemampuan perusahaan untuk mempertahankan tingkat pengembalian di atas rata-rata.

Menurut Porter (2008) ada 5 (lima) kekuatan kompetitif yang mencerminkan fakta bahwa persaingan dalam suatu industri yaitu:

1. Ancaman masuknya calon pendatang baru.

2. Ancaman penggantian produk atau layanan.

3. Daya tawar pembeli.

4. Daya tawar pemasok (pemasok).

5. Persaingan di antara pesaing yang ada.

Lima kekuatan kompetisi di atas bersama menentukan intensitas persaingan dan profitabilitas dalam industri dan kekuatan yang paling kuat akan menentukan dan menjadi sangat penting ketika dilihat dari titik perumusan strategi.

\section{Analisis SWOT}

Analisis SWOT (Strength Weakness Opportunity Threat) adalah analisis yang digunakan untuk mengetahui seberapa besar faktor internal dan eksternal akan mempengaruhi perusahaan. Pendekatan ini merupakan evaluasi untuk mengubah faktor negatif baik dari kelemahan perusahaan dan ancaman pasar menjadi faktor positif kekuatan dan peluang dari faktor eksternal (Thompson \& Strickland, 2007).

Analisis SWOT didasarkan pada konsep dasar bahwa ada dua faktor yang mempengaruhi keberhasilan perusahaan. Singh \& Kohli (2006) menjelaskan faktor pengaruh pertama adalah faktor dalam pengendalian manajemen karena itu harus diakali untuk mengoptimalkan / memaksimalkan keunggulan dan meminimalkan kelemahan. Faktor kedua adalah faktor di luar kendali manajemen yang dicoba dieksploitasi (peluang) dan dihilangkan (ancaman).

David (2011) menjelaskan bahwa analisis lingkungan strategis merupakan bagian dari komponen perencanaan strategis dan merupakan proses untuk selalu menempatkan perusahaan dalam posisi yang strategis, sehingga dalam perkembangannya akan selalu berada pada posisi yang menguntungkan. Ruang lingkup analisis lingkungan strategis meliputi analisis lingkungan internal dan analisis lingkungan eksternal. 


\section{Analisis lingkungan internal}

Analisis lingkungan internal pada dasarnya merupakan proses identifikasi yang terurai menjadi kekuatan dan kelemahan yang mencakup perusahaan, sumber daya manusia, pembiayaan, efektivitas dan efisiensi, fasilitas dan infrastruktur, dan lain-lain yang memiliki pengaruh pada pengambilan kebijakan / keputusan perusahaan. Analisis lingkungan internal pada dasarnya mencakup dua aspek, yaitu kekuatan (kekuatan) dan kelemahan (kelemahan).

- Kekuatan

Merupakan kekuatan yang dimiliki oleh perusahaan biasanya berujud sumber daya yang dimiliki oleh perusahaan baik sumber daya manusia maupun sumber daya lainnya. Ini termasuk: tenaga kerja, goodwill, modal, permesinan, dan sebagainya.

- Kelemahan

Merupakan kelemahan atau kendala yang menyebabkan perusahaan sulit untuk menumbuhkan atau meningkatkan kinerja perusahaan. Kelemahan ini bisa menjadi variabel yang sama dengan kekuatan perusahaan. Seperti tenaga kerja tidak terampil, modal usaha yang tidak mencukupi, kapasitas mesin yang tidak memadai dan sebagainya.

\section{Analisis lingkungan eksternal}

Analisis lingkungan eksternal adalah upaya untuk mengidentifikasi dan menganalisis berbagai faktor lingkungan eksternal seperti pengaruh sosial, politik, ekonomi, ekologi, teknologi, dan perkembangan lain yang memiliki pengaruh terhadap kebijakan perusahaan. Analisis lingkungan eksternal pada dasarnya mencakup dua aspek, yaitu peluang dan ancaman.

- Peluang

Peluang adalah peluang bagi perusahaan untuk tumbuh. Peluang di sini dapat tersedia di lingkungan. Variabel ini tidak dapat disediakan oleh perusahaan. Perusahaan hanya menyesuaikan dengan peluang yang muncul.

- Ancaman

Variabel ini juga tidak dapat dibuat oleh perusahaan. Ancaman ini juga tidak bisa dihilangkan, tetapi intensitas bisa diminimalisir untuk muncul. Contoh kebijakan pemerintah pusat yang tidak konsisten, kendala keuangan lokal, dan sebagainya.

Kunci keberhasilan perusahaan terletak pada kemampuannya untuk beradaptasi dan beradaptasi dalam lingkungan yang selalu berubah. Cara dan waktu yang tepat untuk bereaksi akan menentukan apakah suatu perusahaan bertahan dan berkembang dalam lingkungan yang selalu berubah (Peng et al, 2008). Perubahan lingkungan yang terjadi selalu mudah diamati setiap hari. Gejala ketidakstabilan lingkungan, seperti globalisasi teknologi, tingginya tingkat inflasi, pengangguran, dan sebagainya. 


\section{METODE PENELITIAN}

Penelitian ini menggunakan metode analisis kualitatif, dengan pengumpulan data berasal dari data primer yang diperoleh dari wawancara dan observasi. Sedangkan untuk analisis data menggunakan analisis SWOT. Dalam analisis SWOT dijelaskan bahwa penentu utama dari proses perumusan strategi adalah evaluasi atau identifikasi faktor eksternal dan internal. Selanjutnya porter menekankan bahwa hal yang paling penting dalam membangun strategi keunggulan kompetitif adalah menghubungkan organisasi dengan lingkungannya. Dengan demikian pembentukan strategi harus berasal dari analisis faktor internal dan eksternal.

Analisis SWOT akan sangat berguna untuk mengetahui berapa banyak faktor eksternal dan faktor internal akan mempengaruhi organisasi. Analisis ini merupakan evaluasi untuk mengubah faktor negatif yang berasal dari Weakness and Threath, menjadi Strength and Opportunity (Helms \& Nixon, 2010) faktor positif. Setelah mengidentifikasi dan memberikan bobot dan peringkat faktor eksternal (peluang dan ancaman) dan faktor internal (kekuatan dan kelemahan), maka akan dapat mengetahui posisi kredit karyawan BPR Bhakti Daya Ekonomi dalam diagram SWOT. Kemudian dari hasil analisis SWOT akan diketahui strategi matrik yang akan menggambarkan faktor-faktor penghambat dan faktor penentu keberhasilan BPR Bhakti Daya Ekonomi dalam melakukan strategi pemasaran untuk dapat bersaing dengan pesaing terdekatnya, terutama BRI dan BPD. Untuk memberikan gambaran yang jelas tentang beberapa strategi alternatif dalam diagram SWOT dapat digambarkan sebagai berikut:

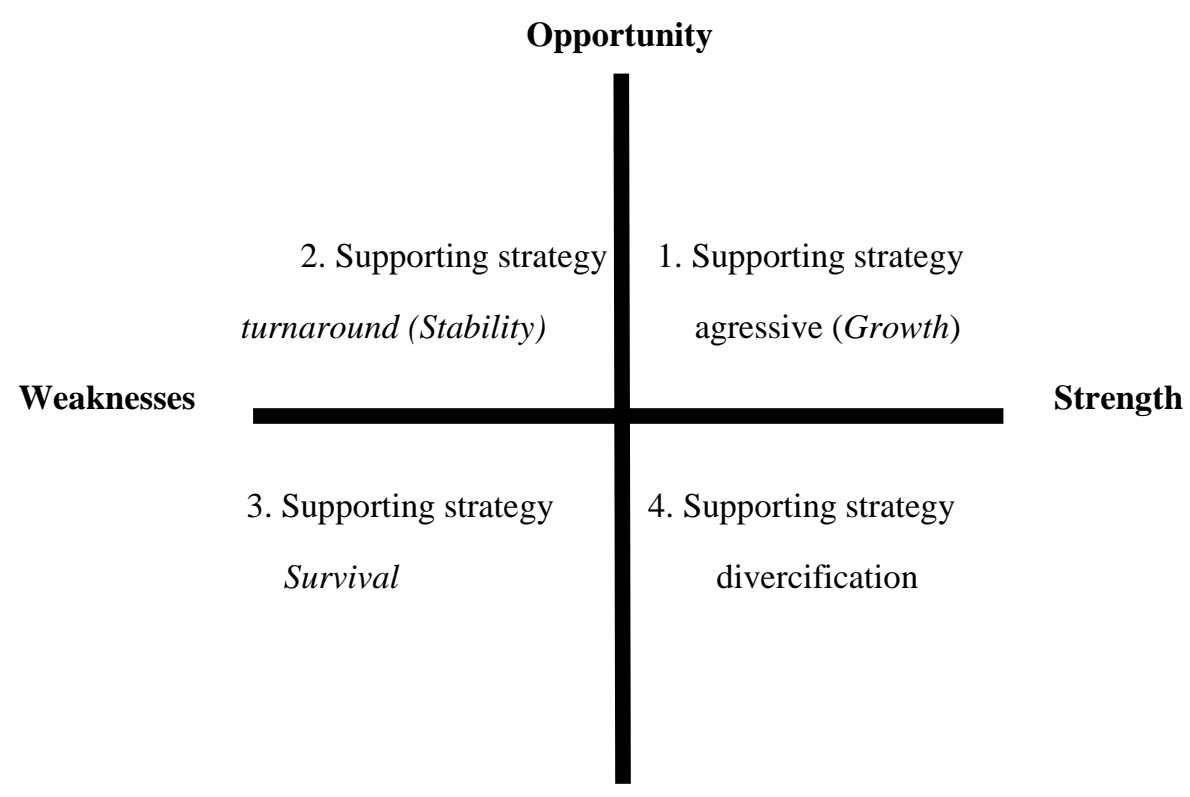

Threats

Gambar 2. Analisis SWOT

(Rangkuti, 2006) 
Penjelasannya adalah sebagai berikut:

Kuadran 1: Adalah situasi yang sangat menguntungkan, perusahaan memiliki peluang dan kekuatan sehingga dapat memanfaatkan peluang. Strategi yang akan diterapkan dalam kondisi ini adalah untuk mendukung kebijakan pertumbuhan yang agresif.

Kuadran 2: Perusahaan menghadapi peluang pasar yang sangat besar, tetapi di sisi lain menghadapi beberapa kendala internal / kelemahan. Fokus dari strategi perusahaan ini adalah untuk meminimalkan masalah internal perusahaan sehingga dapat merebut peluang pasar yang lebih baik. Kuadran 3: Di kuadran ini perusahaan berada dalam situasi yang sangat tidak menguntungkan, perusahaan menghadapi berbagai ancaman dan kelemahan internal.

Kuadran 4: Dalam menghadapi berbagai ancaman perusahaan masih memiliki kekuatan internal. Strategi yang akan diterapkan adalah menggunakan kekuatan untuk mengambil keuntungan dari peluang jangka panjang dengan menggunakan strategi yang terdiversifikasi untuk produk dan pasar yang ditargetkan.

\section{HASIL DAN PEMBAHASAN}

Untuk merespon secara efektif terhadap perubahan lingkungan, BPR Bhakti Daya Ekonomi harus selalu melihat lingkungan internal dan eksternalnya. Menurut Bryson (2011), mereka harus mengamati (Watch). Tetapi mereka juga harus menafsirkan apa yang dilihat. Dalam pelaksanaan perencanaan strategis, adalah memberikan informasi tentang kekuatan internal dan kelemahan organisasi dalam hal peluang internal dan ancaman yang dihadapinya. Pendekatan penilaian lingkungan eksternal dan internal untuk BPR Bhakti Daya Ekonomi akan menjadi sarana untuk mengidentifikasi isu-isu strategis, dan akan memberikan informasi yang berharga untuk langkah selanjutnya. Isu-isu strategis biasanya berhubungan dengan bagaimana organisasi (dalam) berhubungan dengan lingkungan yang lebih besar (di luar) di mana organisasi adalah penghuni. Setiap strategi yang efektif akan mendapat manfaat dari kekuatan dan peluang sambil meminimalkan atau mengatasi kelemahan dan ancaman.

Dari data primer yang telah dikumpulkan tentang faktor eksternal (peluang dan ancaman), dan faktor internal (kekuatan dan kelemahan) yang ada di BPR Bhakti Daya Ekonomi, maka langkah selanjutnya adalah mencari nilai rata-rata tertimbang (Weight Score) internal faktor serta faktor eksternal sebagai dasar pembentukan diagram SWOT. Dengan mengetahui besarnya nilai rata-rata tertimbang faktor eksternal dan faktor internal maka akan dapat diketahui pula posisi BPR Bhakti Daya Ekonomi dalam diagram SWOT. Diagram SWOT sendiri terdiri dari dua sumbu yaitu sumbu vertikal yang merupakan sumbu faktor eksternal (peluang dan ancaman), serta sumbu horizontal yang merupakan sumbu faktor internal (kekuatan dan kelemahan).

Besarnya nilai matriks strategi dapat diperoleh dengan mengalikan bobot dengan skor rata-rata setiap variabel. Setelah bobot dan nilai rata-rata dari setiap variabel dikalikan, langkah selanjutnya adalah menjumlahkan semua nilai tertimbang yang terkandung dalam setiap variabel. Nilai total ini 
menunjukkan besarnya nilai matriks strategi internal dan matriks strategi eksternal yang juga menunjukkan bagaimana manajemen BPR Bhakti Daya Ekonomi bereaksi baik terhadap faktor strategis internal maupun eksternal. Nilai total ini juga akan menggambarkan profil BPR Bhakti Daya Ekonomi dalam diagram SWOT dilihat dari peluang dan ancaman serta kekuatan dan kelemahannya. Hasilnya adalah sebagai berikut:

\section{Tabel 2. Faktor Internal Strategis Matriks}

\begin{tabular}{|c|c|c|c|c|}
\hline No. & Faktor Kekuatan & Poin & $\begin{array}{l}\text { Skor } \\
\text { Mean }\end{array}$ & $\begin{array}{l}\text { Skor } \\
\text { Bobot }\end{array}$ \\
\hline 1 & $\begin{array}{l}\text { Nama BPR BDE sudah dikenal luas pada masyarakat } \\
\text { DIY sehingga dapat /mampu mengangkat produk } \\
\text { kredit pegawai pada posisi yang baik. }\end{array}$ & 0.031 & 3.800 & 0.118 \\
\hline 2 & $\begin{array}{l}\text { Nama BPR BDE yang dikenal sebagai "bank pelopor } \\
\text { pengentas kemiskinan" mampu mengangkat citra di } \\
\text { masyarakat khususnya calon nasabah/nasabah kredit } \\
\text { pegawai. }\end{array}$ & 0.043 & 3.670 & 0.159 \\
\hline 3 & $\begin{array}{l}\text { Jenjang pendidikan formal yang dimiliki para } \\
\text { karyawan BPR BDE dibanding bank BPD dan BRI. }\end{array}$ & 0.040 & 4.070 & 0.164 \\
\hline 4 & $\begin{array}{l}\text { Skill/keahlian yang dimiliki oleh karyawan BPR.BDE } \\
\text { untuk menghadapi persaingan dibanding bank BPD } \\
\text { dan BRI. }\end{array}$ & 0.040 & 3.800 & 0.152 \\
\hline 5 & $\begin{array}{l}\text { Program pelatihan yang dilakukan untuk menghadapi } \\
\text { persaingan dibanding bank BPD dan BRI. }\end{array}$ & 0.030 & 4.130 & 0.125 \\
\hline 6 & $\begin{array}{l}\text { BPR BDE mempunyai strategi usaha yang berfungsi } \\
\text { sebagai pedoman umum yang memadai dalam } \\
\text { mencapai misi/sasaran umum yang berbeda dengan } \\
\text { bank BRI dan BPD. }\end{array}$ & 0.050 & 3.930 & 0.195 \\
\hline 7 & $\begin{array}{l}\text { BPR BDE mempunyai rencana jangka panjang } 5 \\
\text { tahunan (corporate plan) yang jelas dan sekurang- } \\
\text { kurangnya mencakup bidang permodalan, } \\
\text { penghimpunan dana, penyaluran dana, pengembangan } \\
\text { produk dan sumber daya manusia. }\end{array}$ & 0.036 & 4.070 & 0.147 \\
\hline 8 & $\begin{array}{l}\text { Pelaksanaan tugas dan pekerjaan didasarkan pada } \\
\text { uraian tugas pekerjaan (job description) yang tertulis } \\
\text { secara spesifik dan jelas. }\end{array}$ & 0.036 & 4.270 & 0.154 \\
\hline 9 & $\begin{array}{l}\text { Posisi-posisi strategis dijabat oleh orang-orang yang } \\
\text { memiliki kualifikasi dengan persyaratan jabatan (job } \\
\text { requirement) yang memadai. }\end{array}$ & 0.035 & 3.800 & 0.134 \\
\hline 10 & $\begin{array}{l}\text { Layanan yang berkaitan dengan keramahan dan } \\
\text { hubungan interpersonal yang dilakukan oleh karyawan } \\
\text { BPR BDE terhadap para nasabahnya dibanding bank } \\
\text { BPD dan BRI adalah sudah lebih baik. }\end{array}$ & 0.041 & 3.730 & 0.152 \\
\hline 11 & $\begin{array}{l}\text { Dibandingkan dengan BPD dan BRI, proses pencairan } \\
\text { kredit pegawai pada BPR BDE adalah yang paling } \\
\text { cepat. }\end{array}$ & 0.034 & 4.130 & 0.141 \\
\hline 12 & $\begin{array}{l}\text { Sistem birokrasi dan prosedur yang ada pada BPR } \\
\text { BDE adalah lebih mudah dan tidak berbelit-belit } \\
\text { dibandingkan dengan bank BPD dan BRI. }\end{array}$ & 0.047 & 3.670 & 0.173 \\
\hline
\end{tabular}




\begin{tabular}{clccc}
\hline 13 & $\begin{array}{l}\text { Bagaimana faktor kemudahan dalam persyaratan untuk } \\
\text { pengajuan kredit dibanding bank BPD dan BRI? }\end{array}$ & 0.031 & 3.870 & 0.120 \\
14 & $\begin{array}{l}\text { Respon dari nasabah terhadap sistem jemput bola dan } \\
\text { pelayanan langsung di rumah maupun di instansi dalam } \\
\text { pelayanan kredit pegawai adalah lebih baik dibanding } \\
\text { dengan bank BPD dan BRI. }\end{array}$ & & & \\
15 & $\begin{array}{l}\text { Jangka waktu pinjaman maksimal (5 tahun) pada saat } \\
\text { ini sudah mampu bersaing dengan bank BPD dan BRI. }\end{array}$ & 0.046 & 4.800 & 0.153 \\
$16 \quad \begin{array}{l}\text { Perhitungan perlunasan (percepatan) pada saat ini } \\
\text { sudah mampu bersaing dengan bank BPD dan BRI. }\end{array}$ & 0.031 & 3.870 & 0.189 \\
$17 \quad \begin{array}{l}\text { Sistem penyimpanan barang jaminan pada BPR BDE } \\
\text { apakah sudah memadai (jika dikaitkan dengan adanya } \\
\text { kehilangan barang jaminan) dibanding bank BPD dan }\end{array}$ & 0.040 & 4.200 & 0.168 \\
$\begin{array}{l}\text { BRI. } \\
\text { Lokasi BPR BDE yang berada di Pakem mendukung } \\
\text { peningkatan jumlah nasabah yang ingin mengajukan } \\
\text { permohonan kredit pegawai. }\end{array}$ & 0.045 & 3.730 & 0.169 \\
$19 \quad \begin{array}{l}\text { Jika BPR BDE membuka cabang di Jogjakarta (Kodya } \\
\text { atau mendekati Kodya), akan meningkatkan jumlah } \\
\text { peminjam kredit pegawai. }\end{array}$ & 0.035 & 4.070 & 0.143 \\
Jumlah & & & $\mathbf{2 . 8 7 8}$ \\
\hline
\end{tabular}

\begin{tabular}{clccc}
\hline No. & \multicolumn{1}{c}{ Faktor Kekuatan } & Poin & $\begin{array}{c}\text { Skor } \\
\text { Mean }\end{array}$ & $\begin{array}{c}\text { Skor } \\
\text { Bobot }\end{array}$ \\
\hline 1 & $\begin{array}{l}\text { Promosi baik melalui iklan yang dilakukan oleh BPR } \\
\text { BDE selama ini sudah memadai dibanding bank BPD } \\
\text { dan BR. }\end{array}$ & 0.035 & 2.330 & 0.082 \\
2 & $\begin{array}{l}\text { Promosi baik melalui brosur-brosur yang dilakukan oleh } \\
\text { BPR BDE selama ini sudah memadai dibanding bank }\end{array}$ & 0.041 & 2.400 & 0.099 \\
& $\begin{array}{l}\text { BPD dan BRI. } \\
\text { Sumber daya manusia yang menangani pemasaran } \\
\text { Kredit Pegawai sudah memadai dibanding bank BPD } \\
\text { dan BRI. }\end{array}$ & 0.044 & 2.200 & 0.097 \\
4 & $\begin{array}{l}\text { Bunga kredit pegawai yang ada pada saat ini mampu } \\
\text { bersaing dengan bank BPD dan BRI. }\end{array}$ & 0.034 & 2.270 & 0.077 \\
5 & $\begin{array}{l}\text { Plafon kredit yang diberikan pada saat ini sudah mampu } \\
\text { bersaing dengan bank BPD dan BRI. }\end{array}$ & 0.038 & 2.130 & 0.081 \\
6 & $\begin{array}{l}\text { Sistem pengadministrasian dengan komputer yang ada } \\
\text { pada BPR BDE sudah memadai dibanding bank BPD } \\
\text { dan BRI. }\end{array}$ & 0.038 & 2.400 & 0.092 \\
7 & $\begin{array}{l}\text { File nasabah yang ada baik dalam bentuk data } \\
\text { elektronik maupu data secar manual keakuratan }\end{array}$ & 0.037 & 2.330 & 0.086
\end{tabular}

Jumlah 
faktor kelemahan dengan nilai matriks faktor kelemahan sebesar 0,611. Dengan menjumlahkan kedua nilai matriks dari faktor kekuatan dan matriks faktor kelemahan $(2,878+0,611)$ kita mendapatkan nilai matriks strategi faktor internal. Nilai ini kemudian akan menggambarkan profil BPR Bhakti Daya Ekonomi dalam diagram SWOT sumbu horizontal.

Tabel 3. Faktor Eksternal Strategis Matriks

\begin{tabular}{|c|c|c|c|c|}
\hline No. & Faktor Kekuatan & Poin & $\begin{array}{l}\text { Skor } \\
\text { Mean }\end{array}$ & $\begin{array}{l}\text { Skor } \\
\text { Bobot }\end{array}$ \\
\hline 1 & $\begin{array}{l}\text { Diberlakukannya penyesuaian terhadap tunjangan yang } \\
\text { diterima akan berpengaruh positif terhadap produk } \\
\text { kredit pegawai. }\end{array}$ & 0.095 & 4.063 & 0.386 \\
\hline 2 & $\begin{array}{l}\text { Peraturan yang dikeluarkan oleh pemerintah (Menteri } \\
\text { Keuangan RI dan Bank Indonesia) dalam bentuk SK dan } \\
\text { SE tentang penetapan CAR minimum untuk BPR } \\
\text { mempengaruhi kredit pegawai secara positif. }\end{array}$ & 0.098 & 3.614 & 0.354 \\
\hline 3 & $\begin{array}{l}\text { Peraturan yang dikeluarkan oleh pemerintah (Menteri } \\
\text { Keuangan RI dan Bank Indonesia) dalam bentuk SK dan } \\
\text { SE tentang penetapan BMPK maksimal untuk BPR } \\
\text { mempengaruhi kredit pegawai secara positif. }\end{array}$ & 0.067 & 3.764 & 0.252 \\
\hline 4 & $\begin{array}{l}\text { Peraturan yang dikeluarkan oleh pemerintah (Menteri } \\
\text { Keuangan RI dan Bank Indonesia) dalam bentuk SK dan } \\
\text { SE tentang penetapan LDR untuk BPR mempengaruhi } \\
\text { kredit pegawai secara positif. }\end{array}$ & 0.045 & 3.937 & 0.177 \\
\hline \multicolumn{2}{|c|}{ Jumlah } & & & 1.169 \\
\hline No. & Faktor Kekuatan & Poin & $\begin{array}{l}\text { Skor } \\
\text { Mean }\end{array}$ & $\begin{array}{l}\text { Skor } \\
\text { Bobot }\end{array}$ \\
\hline 1 & $\begin{array}{l}\text { Dengan adanya kebijakan gaji PNS melalui bank BPD } \\
\text { berpengaruh positif terhadap perkembangan kredit } \\
\text { pegawai bagi BPR BDE. }\end{array}$ & 0.071 & 1.819 & 0.129 \\
\hline 2 & $\begin{array}{l}\text { Dengan adanya perampingan instansi (penggabungan) } \\
\text { berpengaruh positif terhadap produk kredit pegawai. }\end{array}$ & 0.093 & 1.976 & 0.184 \\
\hline 3 & $\begin{array}{l}\text { Dengan adanya kebijakan pemerintah dengan menaikkan } \\
\text { gaji pegawai akan berpengaruh positif terhadap produk } \\
\text { kredit pegawai. }\end{array}$ & 0.105 & 2.134 & 0.224 \\
\hline 4 & $\begin{array}{l}\text { Dengan adanya penyesuaian terhadap tunjangan yang } \\
\text { diterima akan berpengaruh positif terhadap produk } \\
\text { kredit pegawai. }\end{array}$ & 0.044 & 2.567 & 0.113 \\
\hline 5 & $\begin{array}{l}\text { BPR BDE dalam hal penggunaan teknologi informasi } \\
\text { lebih unggul dibandingkan dengan BRI dan BPD yang } \\
\text { ada di wilayah Pakem. }\end{array}$ & 0.109 & 2.134 & 0.233 \\
\hline 6 & $\begin{array}{l}\text { Dengan hadirnya teknologi informasi dan penerapan } \\
\text { international banking oleh BRI dan BPD tidak } \\
\text { berpengaruh terhadap pengembangan kredit pegawai } \\
\text { bagi BPR BDE. }\end{array}$ & 0.046 & 2.299 & 0.106 \\
\hline 7 & $\begin{array}{l}\text { Apakah faktor keamanan nasional (seperti banyaknya } \\
\text { ancaman bom) akan berpengaruh positif secara langsung } \\
\text { atau tidak langsung terhadap perkembangan kredit } \\
\text { pegawai? }\end{array}$ & 0.036 & 2.362 & 0.085 \\
\hline
\end{tabular}


8 Apakah faktor keamanan dalam skala regional (seperti adanya huru hara \& penodongan) akan berpengaruh positif secara langsung atau tidak langsung terhadap perkembangan kredit pegawai?

9 Dengan adanya ekspansi Bank BPD Cabang Sleman dan BRI Cabang Sleman di bisnis retail banking tidak akan mengancam pangsa pasar kredit pegawai khususnya calon nasabah baru karena BPR BDE merupakan penguasa market di Wilayah Pakem.

10 Dengan adanya promosi yang gencar dari bank BPD dan BRI di media cetak maupun elektronik, tidak akan berpengaruh negatif terhadap BPR BDE khususnya untuk produk kredit pegawai

$\begin{array}{lll}0.073 & 2.252 & 0.164 \\ 0.065 & 1.992 & 0.129 \\ & & \\ & & \\ & & \\ & 2.441 & 0.127 \\ & & \\ & & \mathbf{1 . 4 9 5} \\ & & \mathbf{2 . 6 6 4}\end{array}$

Dari tabel 3 dapat dilihat bahwa nilai matriks faktor probabilitas adalah 1,169 dan nilai matriks faktor ancaman adalah 1,495. Dengan melihat kedua nilai matriks faktor, dapat dilihat bahwa faktor ancaman eksternal BPR Bhakti Daya Ekonomi sedikit lebih dominan dibandingkan dengan faktor peluangnya. Dengan menjumlahkan baik nilai peluang dan faktor ancaman matriks $(1,169+$ 1,495), nilai titik matriks dari strategi faktor eksternal adalah 2,664. Nilai ini akan mengilustrasikan profil BPR Bhakti Daya Ekonomi dalam diagram SWOT sumbu vertikal. Selanjutnya, dengan menggunakan faktor-faktor strategis (eksternal dan internal) seperti yang dijelaskan pada tabel 2 untuk faktor internal dan tabel 3 untuk faktor eksternal, dapat disusun SWOT Matrix yang akan menggambarkan posisi Bhakti Bhaya Bhakti Dhaya Economics dalam diagram SWOT yang dapat digunakan sebagai dasar untuk menyusun strategi pemasaran BPR Bhakti Daya Ekonomi dengan memanfaatkan semua kekuatan dan peluang yang tersedia untuk menghilangkan kelemahan dan ancaman tinggi dari lingkungan eksternal. 


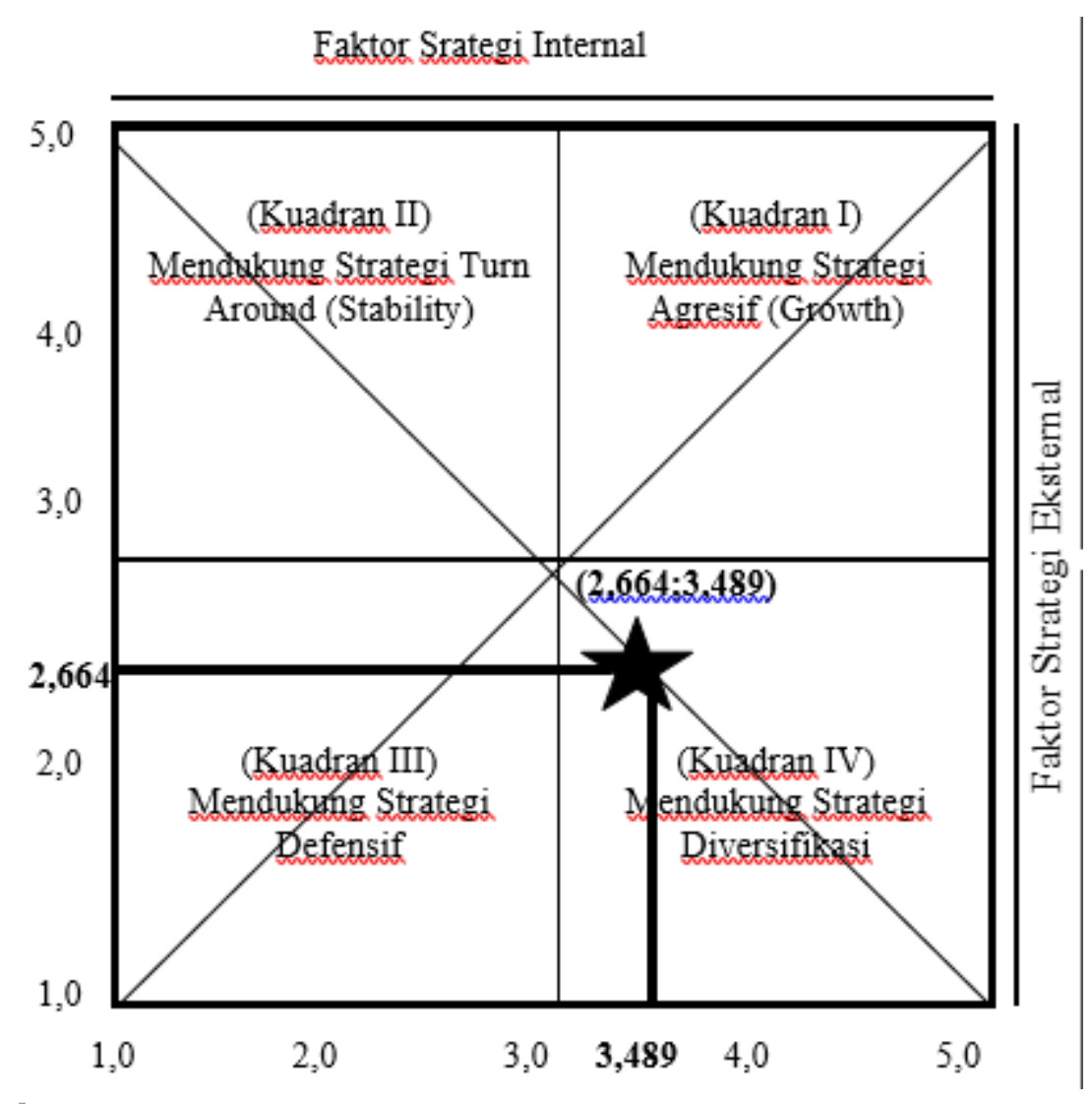

Gambar 3. Matriks SWOT

Dari analisis faktor strategis internal (IFAS) dan analisis faktor strategi eksternal (EFAS), dapat dilihat bahwa nilai titik matriks adalah 2,664 (titik matriks EFAS) dan 3,489 (titik matriks IFAS). Setelah memplot titik-titik matriks faktor internal dan faktor eksternal ke dalam diagram SWOT, dapat dilihat bahwa strategi pemasaran yang paling tepat untuk BPR Bhakti Daya Ekonomi dalam menghadapi persaingan adalah dengan menggunakan strategi SW (Strength \& Weakness), yang berarti BPR Bhakti Daya Ekonomi memiliki kesempatan untuk menggunakan kekuatankekuatan internal untuk meminimalkan ancaman yang dihadapi.

Berdasarkan hasil analisis SWOT dapat dilihat bahwa posisi BPR Bhakti Daya Ekonomi berada di kuadran IV. Dalam kuadran ini, Bank berada dalam posisi di mana kekuatan internalnya relatif lebih dominan daripada kelemahannya. Tetapi dalam menghadapi lingkungan eksternalnya, ancaman yang dihadapi relatif lebih besar daripada kemungkinannya. Ini berarti BPR Bhakti Daya Ekonomi memiliki kemampuan internal yang lebih baik untuk mengembangkan bisnisnya terutama dengan memanfaatkan keunggulannya sendiri. Maka strategi dasar yang tepat dalam situasi ini adalah mengkonsolidasikan untuk mengatasi ancaman yang dihadapi, dengan mendiversifikasi bisnis sesuai dengan kemampuan yang ada. Besar atau kerasnya usaha konsolidasi internal ini tergantung pada ukuran atau besarnya keunggulan internal dibandingkan dengan kelemahannya. Semakin besar 
manfaatnya, upaya konsolidasi relatif kecil. Sebaliknya, lebih sedikit keuntungan dengan kelemahan bank internal, upaya konsolidasi harus lebih besar.

Dari analisis SWOT dapat diketahui bahwa Poisisi BPR Bhakti Ekonomi berada di bawah garis pembagi. Di daerah ini kekuatan bank relatif lebih besar dibandingkan dengan kelemahannya; Di sisi lain, ancaman dari lingkungan eksternalnya relatif lebih besar dari pada peluang, strategi yang paling tepat untuk kondisi ini adalah melakukan strategi diversifikasi konsentrik, yaitu dalam menjalankan strategi diversifikasi ini, bank perlu membuat pilihan yang selektif. dalam melakukan diversifikasi jenis produk kredit karyawan atau memanfaatkan peluang pasar yang sepenuhnya disesuaikan dengan kekuatan internal mereka. Jadi dapat juga dikatakan bahwa dalam melakukan diversifikasi, bank berkonsentrasi pada potensi pasar tertentu dengan membuat terobosan baru di sektor kredit terkait dengan karyawan / karyawan yang menjadi pelanggannya. Jika selama ini karyawan produk kredit hanya ditujukan untuk Pegawai Negeri Sipil dan TNI / POLRI, maka BPR Bhakti Daya Ekonomi harus mulai melirik dengan membuka layanan Kredit Swasta yaitu pasar serta produk-produk baru untuk BPR Bhakti Daya Ekonomi yang merupakan peluang yang belum selesai.

Mengingat kebijakan pemerintah provinsi Daerah Istimewa Yogyakarta untuk melakukan distribusi gaji melalui Bank Pembangunan Daerah tentu akan menjadi ancaman yang sangat serius bagi BPR Bhakti Daya Ekonomi, karena dengan kebijakan tersebut tidak menutup kemungkinan munculnya ikatan emosional. pegawai negeri dari Bank Pembangunan Daerah akan membawa sinergi yang sangat positif dengan kredit pegawai negeri yang jelas terlihat. Kebijakan pemerintah tentu akan sangat merugikan BPR Bhakti Daya Ekonomi, yang pendapatan kreditnya masih sangat tergantung pada produk kredit karyawan. Kondisi saat ini tidak merasakan dampak yang signifikan, tetapi dalam periode yang tidak segera yakin dampak kebijakan akan mulai terasa. Dengan kebijakan pemerintah, Bank Pembangunan Daerah mampu memberikan layanan "One Stop Service" sehingga akan lebih efisien dan dapat menghemat biaya operasional, sehingga BPD dapat mengurangi biaya bunga kepada karyawan kredit. Kondisi ini tentu akan semakin memperumit posisi BPR Bhakti Daya Ekonomi karena kelemahan internal yang selama ini menjadi kendala bagi kemajuan pinjaman karyawan terletak pada biaya bunga yang terlalu tinggi dibandingkan dengan BPD dan BRI.

Melihat fakta-fakta di atas, BPR Bhakti Daya Ekonomi harus berani melakukan terobosan baru untuk segera melepaskan diri dari ketergantunganya ke produk kredit karyawan, terutama PNS dan TNI / POLRI dengan menggarap segmen baru yang lebih potensial yaitu produk kredit dari pegawai swasta. Berdasarkan data Inter-University Center 
(PAU) bekerja sama dengan Bank Indonesia mencatat bahwa usaha kecil mendominasi kegiatan ekonomi regional dengan sekitar 140 ribu dan sekitar 6000 perusahaan yang memiliki SIUP, mereka adalah pasar potensial untuk BPR Bhakti Daya Ekonomi. Bank-bank komersial dengan sistem birokrasi mulai dari jaminan pemerintah, proses dan aturan yang harus dilakukan oleh manajemen bank adalah kelemahan internal bank-bank komersial yang dapat dimanfaatkan oleh BPR Bhakti Daya Ekonomi. Jadi di sini tampak perbedaan yang sangat signifikan dari perbankan umum dan bank-bank pedesaan yang bergerak di sektor riil dalam berbisnis. Bank-bank komersial menjalankan bisnis mereka dengan konsep "Bisnis mengikuti birokrasi" sementara sebaliknya BPR bergerak di sektor riil menggunakan konsep "Birokrasi untuk mengikuti bisnis".

\section{KESIMPULAN DAN SARAN}

Dengan mempertimbangkan matriks faktor internal (kekuatan dan kelemahan) dan matriks faktor eksternal (peluang dan ancaman) berarti BPR Bhakti Daya Ekonomi memiliki kekuatan internal yang relatif lebih baik untuk memperluas bisnisnya, terutama dengan memanfaatkan kekuatan dan peluangnya. Dari hasil analisis matriks faktor internal (IFAS) diperoleh nilai sebesar 3,489 dan matriks faktor eksternal (EFAS) diperoleh nilai 2,664. Dengan mengilustrasikan dua poin matriks dapat dilihat bahwa posisi BPR Bhakti Daya Ekonomi untuk produk Kredit Karyawan berada di kuadran IV. Dalam kuadran ini bank berada dalam posisi di mana keunggulan internalnya relatif lebih dominan daripada kelemahannya. Namun, dalam menghadapi lingkungan ancaman relatif lebih besar daripada peluang. Ini berarti bahwa bank memiliki kemampuan internal yang relatif lebih baik untuk memperluas bisnisnya, terutama dengan memanfaatkan beberapa kekuatan internalnya. Saran dalam penelitian ini adalah dari matriks SWOT dapat diketahui bahwa strategi yang tepat untuk BPR Bhakti Daya Ekonomi adalah melakukan strategi diversifikasi konsentrik karena keunggulan BPR Bhakti Daya Ekonomi relatif lebih besar dibandingkan dengan kelemahan internal, di sisi lain ancaman dari lingkungan eksternal relatif lebih besar daripada peluang yang dimiliki. Caranya adalah dengan menjaga kredit karyawan yang tidak hanya melayani PNS dan TNI / POLRI, tetapi menambah produk baru yaitu pinjaman pegawai swasta yang khusus menargetkan pasar pegawai swasta yang memiliki penghasilan tetap, adapun jaminan kredit yang disalurkan (kehati-hatian perbankan) penulis mengemukakan bahwa BPR.Bhakti Daya Ekonomi harus memperoleh jaminan baik perusahaan maupun pribadi dari manajemen jika sewaktu-waktu karyawan keluar dari perusahaan dan ada jaminan yang dapat secara hukum mengikat (perdata) atas kredit yang diberikan. 


\section{DAFTAR PUSTAKA}

Bryson, J. M. (2011). Strategic planning for public and nonprofit organizations: A guide to strengthening and sustaining organizational achievement (Vol. 1). John Wiley \& Sons.

David, F. R. (2011). Strategic management: Concepts and Cases. Peaeson/Prentice Hall.

Helms, M. M., \& Nixon, J. (2010). Exploring SWOT analysis-where are we now? A review of academic research from the last decade. Journal of strategy and management, 3(3), 215-251.

Noe, R. A., Hollenbeck, J. R., Gerhart, B., \& Wright, P. M. (2009). Gaining a competitive advantage. Irwin: McGraw-Hill.

Peng, M. W., Wang, D. Y., \& Jiang, Y. (2008). An institution-based view of international business strategy: A focus on emerging economies. Journal of International Business Studies, 39 (5), 920-936.

Porter, M. E. (2008). Competitive strategy: Techniques for analyzing industries and competitors. Simon and Schuster.

Rangkuti, F. (2006). Analisis SWOT Teknik Membedah Kasus Bisnis. Cetakan Kedua. Jakarta: Gramedia Pustaka Utama.

Singh, D., \& Kohli, G. (2006). Evaluation of private sector banks in India: A SWOT analysis. Journal of Management Research, 6(2), 84.

Thompson, A. A., \& Strickland, A. J. (2007). Strategic management: Concepts and cases. McGraw-Hill/Irvin

Data Bank Indonesia, Desember 2014.

Laporan BPR Bhakti Daya Eknomi, Desember 2016 